\title{
INSTRUMENT DEVELOPMENT OF MANPOWER (M1) NURSING MANAGEMENT BASED ON PROFESSIONAL NURSING CARE METHODS AND JCI ACCREDITATION
}

\author{
Diana Rachmania1), Widyasih Sunaringtyas'2), Dhina Widayati3) \\ 1,2,3) Stikes Karya Husada Kediri, \\ Corresponding e-mail: widiana1925@gmail.com
}

\begin{abstract}
BACKGROUND : Planning in nursing management is based on the results of the assessment from information about the patient, nursing staff, administration, nursing care models and documentation systems. Nursing students at the nursing management profession stage have an important role in studying the condition of nursing management. A valid and reliable assessment instrument is needed to be able to describe the conditions of work in managing nursing management. The aim of this study is to develop an instrument of manpower (M1) in nursing management based on professional nursing care methods and $\mathrm{JCl}$ accreditation.

SUBJECT AND METHODE : The research design combines a qualitative and quantitative approach (mix method) consisting of 2 phase. The population in this study were all nurses (76) at Amelia Hospital. The sample in this study was 20 nurses with purposive sampling technique. The first phase researchers set up the instrument and conduct Small Group Discussions with the head of nursing, the head of the room, and nurses. Phase 2 analyzes the validity and reliability test of the instrument and SGD phase 2 for the delivery of research recommendations.

RESULTS : The results of the validity test show that the Manpower Assessment Instrument (M1) of nursing management has an average $r$ count $>r$ table $(0.643>0.423)$, and the reliability test result was 0.820 . The Manpower (M1) assessment instrument was declared valid and reliable. The Manpower (M1) assessment instrument of nursing management examined the human resources that manage a nursing practice space.

DISCUSSION : With this assessment instrument, the head of the room or the manager of nursing can manage his human resources so as to create a conducive work environment so that the main goal of improving the quality of nursing services can be achieved.
\end{abstract}

Keyword: instrument, manpower, nursing management, profesiional nursing care methods, $\mathrm{JCl}$ acreditation

\section{INTRODUCTION}

Nursing students at the nursing management profession stage, has an important role in assessing the condition of nursing room management (KBK AIPNI Team, 2010). Implementation of functions management and services in nursing management in the scope of nursing, including management functions such as planning, organization, staffing, direction, and control (Simamora, 2012). Planning is based on the results of the assessment of information about the patient, care staff, administration, models of nursing care and documentation systems. Misperception often occurs between students and the head of nurses at the assessment stage because the nursing management assessment instrument already exists in the form of a simple questionnaire and does not yet have instructions on how to complete it, so the manager often thinks that the instrument is less representative of the conditions that occur in the room.

Basically, education has provided a format for assessment prior to the implementation of nursing management but it has not been standardized so that the depth of assessment in each 
room is still often different. Limited references to nursing management make it difficult for students. Changes in development related to the hospital's accreditation system also require continuous updating of management practices so that there is harmony between what students are preparing for and applications in the clinic.

The Professional Nursing Care Method (MAKP) is a framework that defines the four elements: standards, the nursing process, nursing education and the MAKP system. The definition is based on the principles of values that are believed and will determine the quality of production / nursing services (Gillis, 2000). To establish a quality nursing service, of course, based on quality human resources. Therefore management of personnel / human resources in each nursing room is important to do.

There is a need for a valid and reliable assessment instrument as well as standard and standardized guidance with clear instructions on the contents of the nursing management personnel assessment so that it can be used by hospitals and students to be able to describe the condition of the room to be developed better. Based on this, the researcher needs to develop a manpower assessment instrumen (M1) of nursing management based on professional nursing care methods and $\mathrm{JCl}$ acreditation

\section{METHODE}

The research design used is a mix method research that is a qualitative and quantitative research approach. The variable in this study was the development of a nursing management (M1) management instrument based on the Professional Nursing Care Method and $\mathrm{JCl}$ accreditation. The research consisted of 2 phases beginning with developing the personnel assessment instrument according to the professional nursing care method through SGD (Small Group Discussion) with participants namely the nursing field, the head of the room, and some nurses with a total of 10 participants.

Phase 2 analyzes the validity and reliability test of the personnel management (M1) nursing management instrument with a population of 76 nurses. Respondents were 20 nurses through purposive sampling technique.The measuring instrument in this research is the instrument of energy assessment developed to test its validity and reliability

Data analysis consists of 2 stages, namely descriptive analysis and inferential analysis. Descriptive analysis in the form of subjective evaluation of the participants during the Small Group Discussion. Inferential analysis in the form of a test of validity and reliability using the SPSS program with the validity test using Pearson Product Moment Correlation with a 0.05 . The basis for decision making from this test is if the calculated $r$ value for each question item is greater than $r$ table then the instrument is declared valid. The instrument reliability test analysis is based on the internal consistency of the scale with the Cronbach Alpha technique, otherwise reliable if the Cronbach alpha value $>0.6$

\section{RESULTS AND DISCUSSION}


Frequency distribution of general data on the participants of the Phase 1 research, out of 10 participants, most (70\%) participants were $>40$ years old, almost all $(90 \%)$ participants were female, most $(60 \%)$ were the last education participants namely D3 Nursing, most (70\%) participants worked at Amelia Hospital with> 15 years of service, all (100\%) participants were permanent employees of Amelia Hospital.

Frequency distribution of general data 20 respondents carrying out phase 2 research, almost half of respondents (35\%) aged> 40 years, almost all respondents (95\%) were female, almost half (35\%) of respondents worked in Amelia Hospital with years of service> 15 years, almost all $(80 \%)$ of respondents with the last education were D3 Nursing, and almost all respondents (85\%) were permanent employees of Amelia Pare Kediri Hospital.

\section{The Result of 1 st Phase}

The activity in phase 1 was the implementation of Small Group Discussion which discusses the evaluation of the existing instruments and discusses the development of the manpower (M1) assessment instrument of nursing management. The results of these activities were all participants agree to develop the manpower (M1) assessment instrument of Nursing Management was carried out by making 2 types of instruments, consisting of instruments with open questions to ask the head of the room and instruments with closed questions addressed to nurses to make it easier to analyze. That was because of the large number of nurses who were asked, if the manpower assessment instrument is in the form of open questions, it will be quite difficult to analyze the results. It is also important that in addition to developing instruments, clear guidelines / instructions for filling in the assessment instruments are made so that it is easier when filling instruments.

The open question instrument was for the head of the room consists of questions about the organizational structure in providing nursing care, the role of each health worker in service to patients, identification of qualifications of health workers in the room, planning of staff development by the head of the room, identification of the level of patient dependence and identification of needs nursing staff.

The closed question instrument intended for nurses is the same as the open question instrument, the form is not in the form of a question but in the form of a statement towards the nurse's opinion about the existing workforce conditions in the room

\section{The Result of $2^{\text {nd }}$ Phase}

The results of the validity test of the Instrument Development of Manpower (M1) Asssessment on Nursing Management can be seen in table 1.1

Table 1.1 shows the results of the validity of the Manpower (M1) Assessment instrumen of Nursing Management based on the Professional Nursing Care Method through the Pearson Correlation Product Moment Test with a significance level of a 0.05 for 20 respondents.

Table 1.1 Test Validity Development of Labor Assessment Instrument (M1) Nursing Management based on Professional Nursing Care Methode 


\begin{tabular}{clccc}
\hline No. & Question Item & R Count & $\begin{array}{c}\text { R Table } \\
\text { (N=20) }\end{array}$ & Conclution \\
\hline 1 & Question 1 & 0,618 & 0,423 & Valid \\
2 & Question 2 & 0,535 & 0,423 & Valid \\
3 & Question 3 & 0,865 & 0,423 & Valid \\
4 & Question 4 & 0,506 & 0,423 & Valid \\
5 & Question 5 & 0,659 & 0,423 & Valid \\
6 & Question 6 & 0,845 & 0,423 & Valid \\
7 & Question 7 & 0,575 & 0,423 & Valid \\
8 & Question 8 & 0,630 & 0,423 & Valid \\
9 & Question 9 & 0,691 & 0,423 & Valid \\
10 & Question 10 & 0,506 & 0,423 & Valid \\
\hline
\end{tabular}

In the table 1.1 it was seen that all item items on the instrument have $R$ count> $R$ table (0.423) so that the M1 assessment instrument in Nursing Management is declared valid

Table 1.2 Reliability Test Development of Labor Assessment Instrument (M1) Nursing Management based on Professional Nursing Care Methods

\begin{tabular}{clccc}
\hline No. & Variable & Cronbach alpha & $\begin{array}{l}\mathbf{R} \text { Table } \\
(\mathbf{N}=\mathbf{2 0})\end{array}$ & Conclution \\
\hline 1 & $\begin{array}{l}\text { Manpower (M1) Asssessment } \\
\text { Instrumen }\end{array}$ & 0,820 & 0,423 & Reliabel \\
\hline
\end{tabular}

How to make decisions for reliability can be done in 2 ways, namely by comparing the value of $r$ count $>$ from $r$ table or by if the value chronbach alpha $>0.6$ then the questionnaire declared reliable. Table 1.3 shows the results of the reliability of the Manpower (M1) Assessment instrumen on Nursing Management instrument based on the Professional Nursing Care Method through the Cronbach alpha test with a significance level of a 0.05 for 20 respondents. In the table it can be seen that the Cronbach alpha value> R table (0.423) so that the Nursing assessment (M1) instrument of Nursing Management is declared reliable. Thus the case $r$ count> 0.6 then the instrument declared reliable.

\section{Evaluation of Nursing Management Employment Assessment Instruments based on the Professional Nursing Care Method and JCl}

The evaluation of the assessment instrument begins with the Small Group Discussion (SGD) which is carried out before the instrument trials. It is intended that researchers obtain input from the hospital about the suitability of the contents in the personnel assessment instrument (M1) in nursing management with the conditions and needs that exist in the hospital at this time. The result of SGD is that all participants agree that the development of the Nursing Management (M1) personnel management instrument is due to the development of matters that must be adjusted to the needs of the Hospital accreditation standard.

Accreditation is an acknowledgment of a hospital provided by an independent provider of accreditation institutions established by the Minister, after being assessed that the hospital meets the applicable Hospital Service Standards to improve the quality of hospital services on an ongoing 
basis (Permenkes RI, 2012). Accreditation JCl (Joint Commission International) is an independent, non-profit organization that evaluates and accredits health service organizations (Ziegler, 2019). Every hospital is required to carry out accreditation. This is important to do so that patients get the best service while being treated at the hospital. As stated by the National Guard Health Affairs (NGHA), JCl Accreditation is the most sought after accreditation due to the thoroughness of its process that covers everything from patient entry to discharge and assesses all aspects of management, to meet the standards of the best Hospital in the world (NGHA, 2014). Therefore, every hospital needs to manage its hospital so that it can get good accreditation results from national and international accreditation institutions. The assessment instrument is useful for synchronization between the management of the hospital and the education, so that the results of student assessment during nursing management practice can be used as an evaluation and input in determining policies for the hospital. If the assessment instruments used by students are valid and reliable and in accordance with the needs of the hospital, the existence of the practice of professional students will greatly assist the hospital in managing the room

\section{Analyzing Test Validity and Reliability of the Manpower (M1) Assessment Instrument in Nursing Management}

The results of the study in accordance with table 1.1 states that each item item has a value of $r$ count $>r$ table (0.423), which means the instrument of Manpower (M1) Assessment Instrument on Nursing Management is declared valid. In accordance with table 1.2 shows that the value of cronbach alpha $>\mathrm{R}$ table and also cronbach alpha $>0.6$ which means that the instrument is declared reliable.

The principle of validity is measurement and observation which means the principle of instrument reliability in collecting data. The instrument must be able to measure what should be measured. Validity emphasizes more on measuring devices / observations (Nursalam, 2013). Reliability is the similarity of the results of measurements or observations if the facts or facts of life were measured or observed many times in different times. Tools and methods of measuring or observing both play an important role at the same time (Nursalam, 2013). In accordance with the facts and theories, the assessment instruments developed must contain valid and reliable principles in order to truly be able to measure the things that should be measured. The making of item items in the nursing management personnel assessment instrument refers to a measuring instrument that was previously opened by Nursalam (2017) and the researcher develops in accordance with indicators of room management management based on professional nursing care methods and $\mathrm{JCl}$ (Joit Commission International) accreditation standards.

\section{CONCLUSIONS AND RECOMMENDATIONS}

Nursing management (M1) management instruments based on professional nursing care methods and the Joint Commission International Accreditation Standards are declared valid and reliable.

The suggestion in this research is that in analyzing the results of the instrument it is necessary to synchronize the results of the assessment between the assessment with open questions for the head of the room and the assessment with closed questions for nurses so that they can complement the results of the assessment with each other. 


\section{REFERRENCE}

Azizah, Widayati, Rachmania, (2016). Pengaruh Discharge Planning terhadap Kualitas Pelayanan Keperawatan di Rumah Sakit Amelia Pare Kediri. Journals of Nurse Community, Volume 8 Nomor 1. ISSN : 2541-2957

Gillis, DA.(2000). Manajemen Keperawatan: Sebagai Suatu Pendekatan Sistem. Bandung: IAIKP

Huber, Diane L. (2010). Leadership and Nursingcare Management, fourth edition, Philadelphia: Sounders Elseiver.

Kurniadi, Anwar (2013). Manajemen Keperawatan dan Prospektifnya, Jakarta, Badan FKUI.

Mahlinda, (2010), Instrumen penelitian. http://mahlindasetulushati.blogspot.co.id/2010/06/instrumen-penelitian.html. Diakses 3 Agustus 2018.

NGHA (National Guard Health Affairs), (2014). Define Accreditation in Medical Cities. www.ngha.med.sa/English/AboutNGHA/Pages/Accreditation.aspx

Nursalam, (2013), Metodologi Penelitian IImu Keperawatan, Salemba Medika, Jakarta

Nursalam, (2017). Manajemen Keperawatan: Aplikasi Dalam Prakyik Keperawatan Profesional, Jakarta, Salemba Medika

Okaisu, E.M., Kalikwani, F., Wanyana, G. \& Coetzee, M. (2014), Improving the quality of nursing documentation: An action research project', Curationis 38(1), Art. \#1251, 11 pages. http://dx.doi. org/10.4102/curationis. v37i1.1251. Diakses Tanggal 3 Agustus 2019

Paans, W., Sermeus, W., Nieweg, R.M.B., Schans, C, 2010. Development and psychometric testing of the $D$-Catch instrument, a measurement instrument for nursing documentation in hospitals. Journal of Advanced Nursing 66 (6).

Peraturan Pemerintah Republik Indonesia No.4 Tahun 2014 tentang Penyelenggaraan Pendidikan Tinggi dan Pengelolaan Perguruan Tinggi

Polit, D.F. \& Hungler, B.P, (1997), Essential of Nursing Reserach: Method, apraisal, and utilization. Fourth edition. Philadelphia: Lippincot

Rachmania, Nursalam, Yunitasari. (2016). Pengembangan Instrumen Diagnosis dan Intervensi Keperawatan berbasis Standardized Nursing Language (NANDA-I, NOC, NIC). JURNAL NERS Vol. 11/No.2/Published: 2016-10. E-ISSN: 2502-5791

Simamora, Roymond H. (2012). Buku Ajar Manajemen Keperawatan. Jakarta. EGC

Staub, M.M., Lunney, M., Lavin M.A., Needham, I., Odenbreit,M., Achterberg, Tv, (2008), Testing the Q-DIO as an instrument to measure the documented quality of nursing diagnosis, intervention, and outcomes. International Journal of Nursing Terminologies and Classifications; 19, 1 
Sullivan DT et all, (2009), Assessing quality and safety competencies of graduating prelicensure nursing students, https://www.sciencedirect.com/ science/article/abs/pii/S0029655409001420, Diakses tanggal 10 Agustus 2019

Wang N. , Hailey D. \& Yu P, (2011), Quality of nursing documentation and approaches to its evaluation: a mixed-method systematic review. Journal of Advanced Nursing 00(0), 000 000. doi: 10.1111/j.1365-2648.2011.05634.x. Diakses Tanggal 6 Agustus 2019

Ziegler, Helen, (2019). What is $\mathrm{JCl}$ Acreditation. www.hziegler.com. Diakses tanggal 20 Agustus 2019 